\title{
aniki
}

Revista Portuguesa da Imagem em Movimento

Portuguese Journal of the Moving Image

\section{Infiltrados e Invasores: Uma perspectiva comparada sobre relações de classe no cinema brasileiro}

\section{Luana Cabral}

Instituto de Arte e Comunicação Social, Universidade Federal Fluminense

luanam.cabral@gmail.com

https://orcid.org/0000-0001-5252-957X

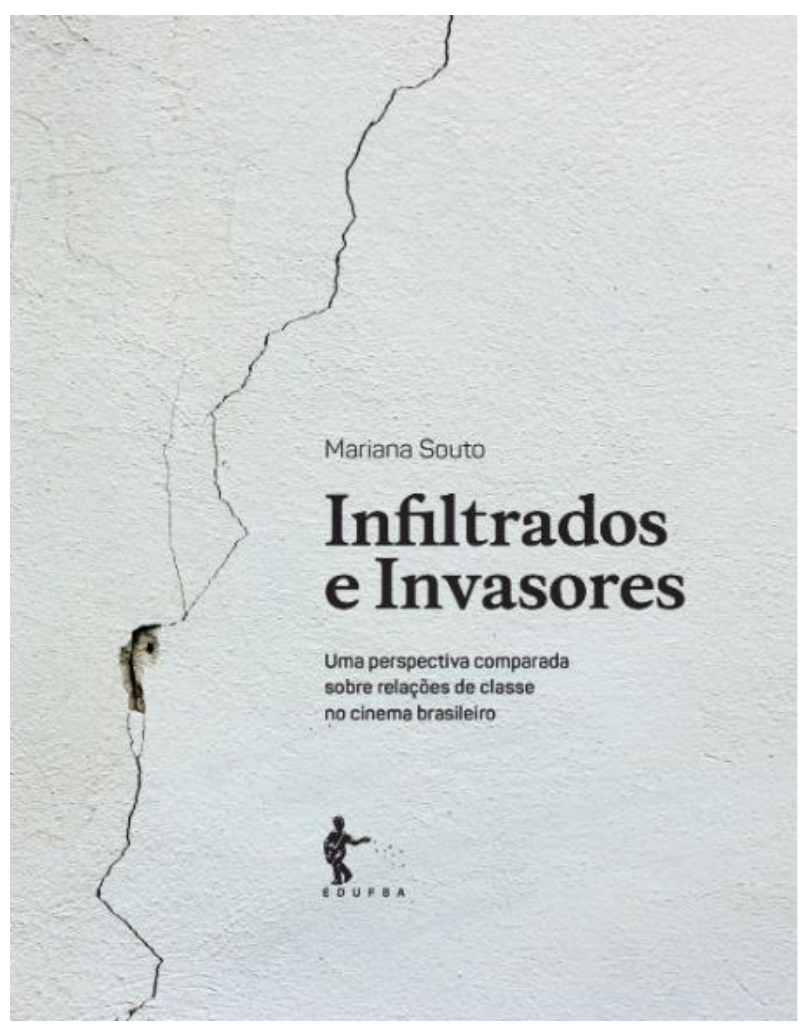

Souto, Mariana. 2019. Infiltrados $e$ Invasores: Uma perspectiva comparada sobre relações de classe no cinema brasileiro. Salvador: EDUFBA. 252 pp. ISBN 978-85-2321921-5.

Originalmente apresentado como tese de doutorado de sua autora, Mariana Souto, defendida na Universidade Federal de Minas Gerais (UFMG, Brasil), o livro Infiltrados e Invasores: Uma perspectiva comparada sobre relações de classe no cinema brasileiro concentra sua análise no período pós-Retomada, embora a autora não se furte de estabelecer conexões também com o 
cinema do passado. ${ }^{1}$ Assim, seus objetos de análise são discutidos a partir de um motivo em comum: as relações de classe no cinema brasileiro e as mutações, rupturas e diálogos existentes entre os filmes. Além de embasar-se na obra de importantes teóricos do cinema brasileiro como Jean Claude-Bernardet e Ismail Xavier, Souto dialoga também com autores como Walter Benjamin, Michel Foucault e Jacques Aumont, especialmente no primeiro capítulo de seu livro, dedicado à discussão da metodologia empregada no estudo em questão que, como a própria coloca, relaciona-se de maneira intrínseca ao seu próprio problema de pesquisa (p. 40). Numa perspectiva comparativa, a pesquisadora propõe as noções de inventário, coleções e séries como ferramentas para analisar, comentar e propor a partir dos objetos em questão. Especialmente interessante é a transposição da ideia de "constelação", em alusão à metáfora usada por Walter Benjamin (1984), como um recurso visual empregado em ilustrações presentes nos capítulos do livro. Essas constelações são mapas conceituais que tratam de organizar seus objetos a partir das relações que sustentam entre si e das ligações que assim se estabelecem (p. 49).

No capítulo "De peões a domésticas: uma série histórica", partimos de filmes como Viramundo (1965) e $A B C$ da Greve (1979-90) que mostram o trabalho e a figura do operário a partir daquilo que Bernardet (2003) propõe como "modelo sociológico" do documentário brasileiro, cuja principal linha de força é a construção de tipos, num recorrente esmagamento das singularidades decorrente da busca por uma imagem ideológica, correspondente a alguma expectativa ou teoria (p. 53). A partir de Peões (2004), essas imagens passam a ser tensionadas pelo deslocamento dos operários do corpo de trabalho das fábricas em direção ao espaço doméstico, e uma significativa abertura às suas individualidades, "suas opiniões, desejos e sentimentos" (p. 66). Também em Peões começa a ser questionado o papel do cineasta em relação ao seu entrevistado, gesto que será intensamente explorado em filmes como Doméstica (2012), Babás (2010) e Santiago (2007), discutidos no capítulo seguinte, intitulado "Relações de poder em casa e em cena". Nos três, a noção de trabalho também se desloca da tradicional fábrica para o espaço doméstico, por

\footnotetext{
${ }^{1}$ O fim da Embrafilme e do Ministério da Cultura nos anos 1990, durante o governo do presidente Fernando Collor de Melo, impossibilitou a maior parte da produção cinematográfica no país. 0 período que se sucede a este "apagão" ficou conhecido como Retomada e foi marcado pela criação de leis de incentivo, entre as quais a Lei do Audiovisual, e o consequente restabelecimento da produção, entre 1995 e 1999. 0 cinema realizado a partir dos anos 2000 por vezes é nomeado "cinema pós-retomada", marcando uma ruptura no contexto de realização das obras, nas políticas culturais existentes no país, no volume e na recepção das produções.
} 
vezes explorando as questões de gênero em intercessão com os problemas de classe.

Distanciando-se cada vez mais de "modelos sociológicos" de representações de classe, o livro encontra-se, nos capítulos subsequentes, com cinemas erigidos às custas de processos de infiltração, muitas vezes valendo-se de dispositivos cinematográficos e, eventualmente, com propostas narrativas e estéticas radicais. Em "Dispositivos e Infiltração", são discutidos principalmente Pacific (2009) e Doméstica (2012), "filmes-dispositivos em que personagens filmam outros personagens", conforme define a própria autora (p. 119). Em ambos, a câmera é entregue a personagens implicados no contexto estudado pelo filme para que registrem a si próprios ou a pessoas do seu convívio (as empregadas domésticas no filme de 2012, por exemplo, são filmadas pelos filhos ou filhas de seus patrões e de suas patroas). Agindo como cinegrafistas, diretores de cena e também personagens dentro da própria criação, os voluntários tornam-se mediadores da relação entre personagens e cineasta - esses, por sua vez, após lançarem mão da estratégia produtiva que constitui o dispositivo, voltam ao encontro do filme e da posição de enunciadores apenas na sala de montagem.

Ainda dentro da investigação sobre filmes de infiltração, Um Lugar ao Sol (2009), Vista Mar (2009) e Câmara escura (2012) são os objetos de estudo do capítulo "Documentários terroristas: notas sobre tocaia e armadilha". 0 movimento investigado aqui aproxima-se de uma prática de "guerrilha" que tensiona as relações entre terror e território. Entrando no lar do "inimigo", do Outro de classe, os cineastas atingem a essência (possivelmente arquetípica, como ressalta a autora) de seus personagens, representantes de uma classe média ou alta que tem como pilar ideológico a ideia de propriedade privada. Tais filmes representam uma ruptura inegável com a tradição do documentário brasileiro, majoritariamente voltado à escuta atenta e empática dos(as) personagens. Aqui, os anteriormente mencionados dispositivos de infiltração são levados alguns passos adiante, perturbando, de fato, a realidade do outro. Os limites éticos e estéticos desses dispositivos são tensionados no capítulo dadas as especificidades de cada um dos objetos, mas também a partir da comparação com outras obras, tais como A Opinião Pública (1967) e Hiato (2008). Esse tipo de ligação com filmes exteriores ao conjunto analisado é um elemento recorrente em todos os capítulos do livro, que nos ajuda a estabelecer conexões mais dinâmicas entre diversos filmes brasileiros, alguns deles de extrema relevância no 
contexto da filmografia nacional, outros mais recentes ou menos comentados.

Uma coleção de recentes filmes de ficção, realizados entre 2011 e 2015, é discutida no capítulo final, nomeado "Os invasores". Trabalhar Cansa (2011), Eles Voltam (2012), O Som ao Redor (2012), Casa Grande (2014) e Que Horas Ela Volta? (2015) trazem a figura do invasor como o outro de classe que avança pelo território oposto. Em geral, trata-se de situações que envolvem pessoas de classes baixas adentrando o universo da classe média e da classe alta, com a exceção à regra talvez sendo o longa metragem Eles Voltam. Nesses filmes, o espaço habitado pelos personagens é crucial para assinalar o gesto da invasão, definida como "a ultrapassagem de uma barreira social" (p. 213), bem como delimitar o território como um lugar de disputas simbólicas constantes, seja ele um bairro (O Som ao Redor), uma casa dividida entre áreas de patrões e áreas de funcionários (Que Horas Ela Volta?), ou mesmo um supermercado (Trabalhar Cansa).

A presença dos "invasores" favorece aquilo que a autora chama de "rupturas instauradoras", não necessariamente rompendo com a ordem estabelecida, mas promovendo algum tipo de instabilidade ou desconforto (p. 184). Esse tipo de sensação, para além de estar pulverizado na atmosfera dos filmes, não raro leva à criação de um clima de medo - a ameaça de um ataque (p. 213). Alguns desses filmes, portanto, flertam com elementos do cinema de horror, materializando esses medos contemporâneos que atravessam as relações de classe brasileiras, como o medo da invasão, da perda de status ou poder, da desconfiguração de dinâmicas sociais, patronais e familiares. A análise presente no livro evidencia a existência de simbologias visuais e sonoras marcantes desse movimento de construção cinematográfica do medo, como os vultos, as piscinas vazias, a presença de animais ou a animalização dos sujeitos - nesse último caso, fazendo referência também ao filme argentino $O$ Pântano (La Ciénaga, 2001) e seu rato-do-banhado. Em suma, em meio ao mergulho cotidiano nas minúcias de seus personagens, permeadas por complexas dinâmicas sociais que fazem referência ao cenário brasileiro, há algo de macabro que, por sua força, inevitavelmente irrompe na narrativa, muitas vezes na forma de algo sobrenatural.

Dialogando com a tradição da historiografia do cinema brasileiro, ao passo que atualizando-a, Infiltrados e Invasores articula a interdisciplinaridade nos estudos de cinema conjugando o arcabouço teórico de disciplinas do conhecimento como história, sociologia e literatura. É, porém, a perspectiva comparada do cinema que guia o desenvolvimento de sua argumentação e costura seus capítulos: o cinema como fonte, o cinema através do cinema, 
apontando os mais interessantes caminhos de análise. Suas proposições metodológicas dão novo fôlego ao método da análise fílmica comparativa, ferramenta já conhecida dos estudos de cinema que aqui parece adequar-se de maneira exemplar ao estudo proposto. Ao remexer os arquivos do cinema brasileiro, aproximando obras já reverenciadas, como Peões (2004), a filmes tão mais recentes como Que Horas Ela Volta? (2015), Souto oferece uma nova perspectiva sobre as tradições presentes no cinema brasileiro, bem como seu desenvolvimento narrativo, estético e até mesmo mercadológico. Todavia, as relações de classe que são objeto de estudo do livro em questão perpassam também a história de um país e a construção de sujeitos (muitos dos quais cineastas, realizadores dos filmes discutidos no livro) engajados de diferentes maneiras com a dinâmica social brasileira. A complexidade do assunto demanda às linhas retas e ascendentes da História desvios, rompimentos, fios e rupturas, e a isso Infiltrados $e$ Invasores responde com suas instigantes constelações.

\section{Referências}

Benjamin, Walter. 1984. Origem do Drama Barroco Alemão. São Paulo: Brasiliense.

Bernardet, Jean-Claude. 2003. Cineastas e Imagens do Povo. São Paulo: Companhia das Letras.

\section{Filmografia}

$A B C$ da Greve [Documentário] Dir. León Hirszman. Taba filmes/Cinemateca Brasileira, Brasil, 1979-1990. 84 minutos.

A Opinião Pública [Documentário] Dir. Arnaldo Jabor. Sagitário Produções Cinematográficas Ltda./ Verba S.A., Brasil, 1967. 78 minutos.

Babás [Documentário] Dir. Consuelo Lins. Brasil, 2010. 20 minutos.

Câmara Escura [Documentário] Dir. Marcelo Pedroso. Marcelo Pedroso, Brasil, 2012. 25 minutos.

Casa Grande [Ficção] Dir. Fellipe Barbosa. Migdal Filmes/Iafa Britz, Brasil, 2014. 115 minutos.

Doméstica [Documentário] Dir. Gabriel Macaro. Desvia/Fundo de Cultura do Governo do Estado de Pernambuco, Brasil, 2012. 75 minutos. 
Eles Voltam [Ficção] Dir. Marcelo Lordello. Trincheira Filmes, Brasil, 2012. 100 minutos.

Hiato [Documentário] Dir. Vladimir Seixas. Brasil, 2008. 20 minutos.

O Pântano/ La Ciénaga [Ficção] Dir. Lucrecia Martel. Lita Stantic Produciones, Argentina/Espanha/França, 2001. 103 minutos.

O Som ao Redor [Ficção] Dir. Kleber Mendonça Filho. CinemaScópio, Brasil, 2012. 131 minutos.

Pacific [Documentário] Dir. Marcelo Pedroso. Brasil, 2008. 72 minutos.

Peões [Documentário] Dir. Eduardo Coutinho. Videofilmes, Brasil, 2004. 85 minutos.

Que Horas Ela Volta? [Ficção]. Dir. Anna Muylaert. Gullane/Africa Filmes/Globo Filmes, Brasil, 2015. 112 minutos.

Santiago [Documentário] Dir. João Moreira Salles. Videofilmes, Brasil, 2007. 80 minutos.

Trabalhar Cansa [Ficção] Dir. Marco Dutra e Juliana Rojas. Africa Filmes/ Dezenove Sons e Imagens/Ancine: Agência Nacional do Cinema, Brasil, 2011. 99 minutos.

Um Lugar ao Sol [Documentário] Dir. Gabriel Mascaro. Símio Filmes/Plano 9, Brasil, 2009. 66 minutos.

Viramundo [Documentário] Dir. Geraldo Sarno. Caravana Farkas, Brasil, 1965. 37 minutos.

Vista Mar [Documentário]. Dir. Pedro Diógenes. Escola Vila das Artes, Brasil, 2009. 